\title{
The laboratory transmission of Coxsackie A6 virus by mosquitoes
}

\author{
By T. MAGUIRE \\ Virus Research Unit, Medical Research Council, University of \\ Otago Medical School, Dunedin, New Zealand
}

(Received 25 June 1970)

\section{SUMMARY}

Coxsackie A 6 virus, strain V 29, originally isolated from Aedes polynesiensis in Fiji, was found to survive in $A$. australis for 5 days after intrathoracic injection and for 6 days after feeding on viraemic mice, and in Culiseta tonnoiri for 8 days after feeding.

The virus level in both fed and injected mosquitoes fell steadily after infection and never exceeded the original level.

No virus transmission was obtained in 46 successful second feedings on days 10-14 with $A$. australis, but three transmissions were obtained with $C$. tonnoiri, two on day 10 and one on day 13 , from 12 successful second feedings.

\section{INTRODUCTION}

The isolation of nine strains of Coxsackie A6 virus from Aedes (Stegomyia) polynesiensis Marks in Fiji at a time when human Coxsackie infections were known to be occurring (Maguire \& Macnamara, 1966) indicated that mosquitoes might be potential vectors of enteroviruses in nature, and that in certain areas, vector transmission might play a small, but significant, part in the epidemiology of such infections. Several authors have reported the isolation of enteroviruses from flies and other insects (reviewed by Gelfand, 1961), but there have been very few studies on the multiplication or survival of enteroviruses in insects, or on the ability of blood-sucking arthropods to transmit enteroviruses by bite. One brief report has been published on the ability of mosquitoes to support the multiplication of Coxsackie viruses (Taylor, 1955).

In this study, investigations have been made into the survival of Coxsackie A 6 virus in two species of mosquito, and into the transmission of the virus to normal newborn mice by mosquitoes infected by intrathoracic injection of virus or feeding on viraemic newborn mice.

\section{Virus}

\section{MATERIALS AND METHODS}

V 29, one of the original Fiji strains of Coxsackie A 6, was used at the second and third mouse passage levels. Virus suspensions for intrathoracic injection of mosquitoes were prepared from fresh newborn mouse brains harvested $72 \mathrm{hr}$. after 
intraperitoneal (i.p.) injection. Suspensions were made by grinding the brain in a mortar, adding diluting fluid containing calf serum and antibiotics, and clearing the suspension by spinning at $2000 \mathrm{rev} . / \mathrm{min}$. for $5 \mathrm{~min}$. The mice, all random-bred albino stock, were inoculated i.p. within $24 \mathrm{hr}$. of birth and usually developed a viraemia of over $10^{4 \cdot 5} \mathrm{LD} 50 / 0.02 \mathrm{ml}$. by the $48 \mathrm{th} \mathrm{hr}$. after infection and over $10^{6.0} \mathrm{LD} 50 / 0.02 \mathrm{ml}$. by $72 \mathrm{hr}$. when deaths began to occur.

The virus titres in individual mosquitoes and mouse bloods were determined by inoculating 24-hr.-old newborn mice intracerebrally (i.c.) and i.p. simultaneously.

\section{Mosquitoes}

Laboratory-reared Aedes (Halaedes) australis Erichson and field-trapped Culiseta (Climacura) tonnoiri Edwards were used in this study. A. polynesiensis does not occur in New Zealand.

After feeding or injection, infected mosquitoes were kept under controlled conditions of humidity and temperature (mean $20^{\circ} \mathrm{C}$.) in an insectory. Any mosquitoes dying and others taken for virus assay at various intervals after infection were frozen at $-34^{\circ} \mathrm{C}$.

\section{Intrathoracic injection of mosquitoes}

Mosquitoes were lightly anaesthetized with carbon dioxide and then inoculated by injecting virus suspension into the thorax using a Pyrex microcapillary pipette. The average amount of virus injected was calculated by titrating suspensions prepared from several individual mosquitoes, frozen immediately after injection.

\section{Feeding experiments}

Viraemic newborn mice were attached to adhesive tape on wooden blocks which were then placed in cages of mosquitoes. The mice were relatively immobile and could not move sufficiently to discourage probing by the mosquitoes. After several hours at $32-35^{\circ} \mathrm{C}$., the mice were removed and bled for virus assay, and engorged mosquitoes were removed and placed in individual glass vials containing moist cotton-wool covered with filter paper and capped by a circle of mosquito netting. The mosquitoes were kept alive by feeding occasionally with fresh apple slices and by placing a plug of cotton wool soaked in weak sugar solution on top of the netting.

\section{Transmission}

Attempts were made, at various intervals after engorgement or injection, to induce the infected mosquitoes to feed on normal 24-hr.-old mice to see whether or not transmission of the virus could be obtained. The mice were placed on top of the mosquito net cap covering the vial and they were held in place by a second piece of netting placed over them and secured loosely to the vial by a rubber band. The mice were thus immobilized without causing them any discomfort and yet they were directly accessible to the mosquito. To encourage feeding, the mosquitoes were deprived of food and water for 2 or 3 days before exposure to the mice. While this practice increased the death rate quite markedly, it did induce feeding, 
Coxsackie virus transmission by mosquitoes

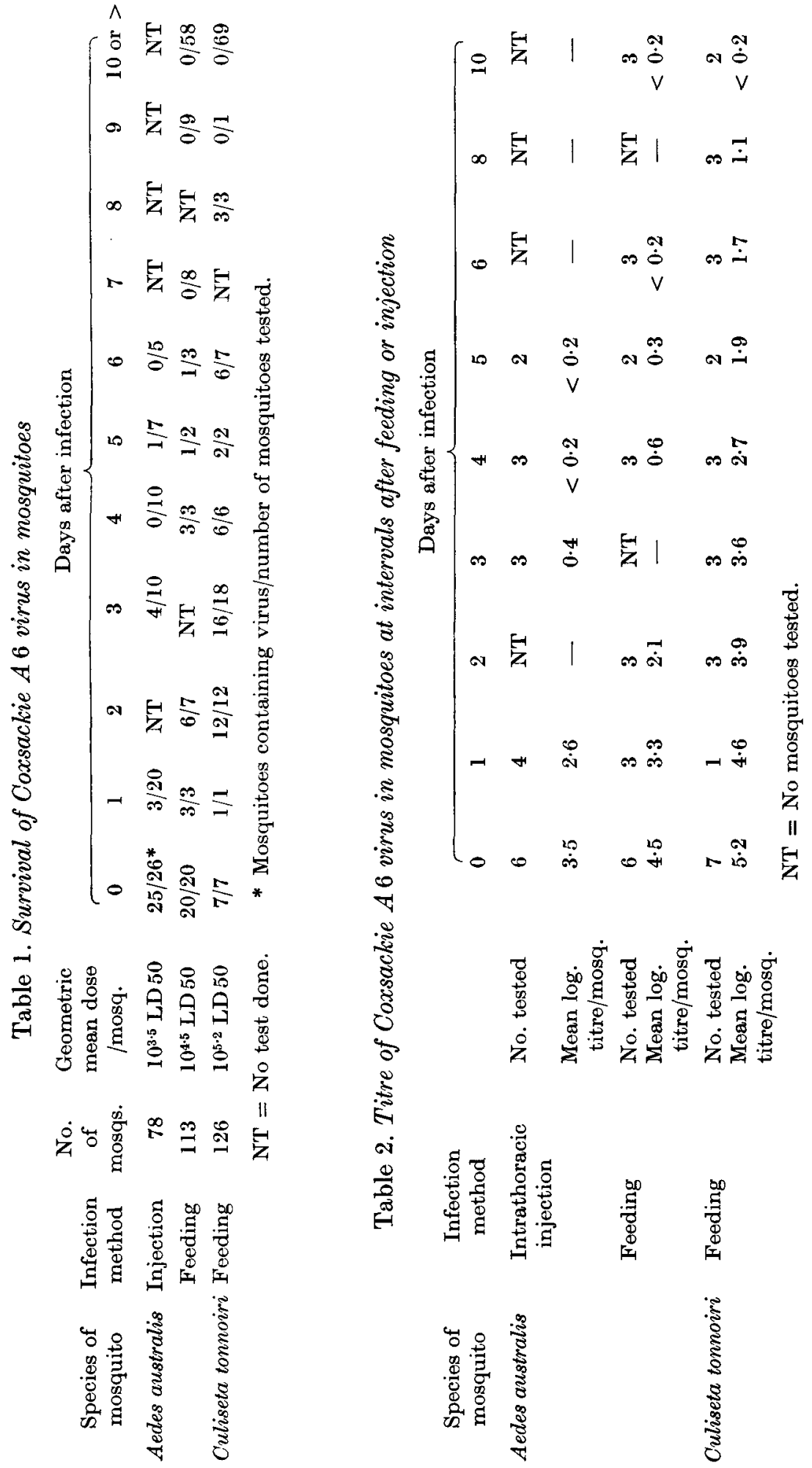


especially with the delicate $C$. tonnoiri. Any mosquitoes which did take a second meal, or which were observed to probe for any length of time, were immediately frozen for subsequent virus assay and the mice were marked by tattoo for identification purposes.

\section{Virus identification}

Virus recovered from mice bitten by infected mosquitoes was identified using a mouse neutralization test incorporating a Coxsackie A6 antiserum of known potency.

Virus survival

\section{RESULTS}

The number of mosquitoes containing detectable virus at various intervals after feeding or injection is shown in Table 1. Table 2 shows the amount of virus in selected mosquitoes at intervals after infection.

\section{Transmission}

Table 3 shows the number of mosquitoes exposed at intervals to uninfected mice and the number of second feedings and transmissions obtained.

Table 3. Transmission studies with Coxsackie $A 6$ in mosquitoes

\begin{tabular}{|c|c|c|c|c|c|c|c|c|c|}
\hline \multirow{2}{*}{$\begin{array}{l}\text { Species of } \\
\text { mosquito }\end{array}$} & & \\
\hline & & 3 & 6 & 9 & 10 & 12 & 13 & 14 & 16 \\
\hline \multirow[t]{3}{*}{$\begin{array}{l}\text { Aedes } \\
\text { australis }\end{array}$} & $\begin{array}{l}\text { Number of infected } \\
\text { mosquitoes exposed } \\
\text { to mice }\end{array}$ & 44 & 40 & 38 & 38 & 30 & 32 & 40 & $\mathrm{NT}$ \\
\hline & $\begin{array}{l}\text { Successful second } \\
\text { feedings }\end{array}$ & 0 & 0 & 0 & 8 & 18 & 8 & 12 & - \\
\hline & $\begin{array}{l}\text { Death in exposed } \\
\text { mice }\end{array}$ & 0 & 0 & 0 & 0 & 0 & 0 & 0 & - \\
\hline \multirow[t]{3}{*}{$\begin{array}{l}\text { Culiseta } \\
\text { tonnoiri }\end{array}$} & $\begin{array}{l}\text { Number of infected } \\
\text { mosquitoes exposed } \\
\text { to mice }\end{array}$ & $\mathrm{N}^{\prime} \mathrm{T}$ & $\mathrm{NT}$ & 30 & 24 & 21 & 20 & 18 & 16 \\
\hline & $\begin{array}{l}\text { Successful second } \\
\text { feedings }\end{array}$ & - & - & 0 & 4 & 3 & 5 & 0 & 0 \\
\hline & $\begin{array}{l}\text { Deaths in exposed } \\
\text { mice }\end{array}$ & - & - & 0 & $2^{*}$ & 0 & $1^{*}$ & 0 & 0 \\
\hline
\end{tabular}

* No virus was detected in the mosquitoes biting these mice. Virus recovered from the mice was identified by neutralization test.

NT $=$ No mosquitoes exposed.

\section{DISCUSSION}

Coxsackie A 6 survived longer in $A$. australis mosquitoes which had had a blood meal than in those which had been infected by injection, and $C$. tonnoiri engorged on mouse blood harboured the virus longer than did the engorged A. australis. Both these observations could be explained on the basis of differences in initial doses. 
It is not surprising that Coxsackie A 6 is capable of surviving for up to 8 days in mosquito tissue since, like most enteroviruses, this virus is relatively stable over a wide range of temperatures, $\mathrm{pH}$ and chemical environment (reviewed by Dalldorf \& Melnick, 1965). There was no evidence of active multiplication of the virus and at no time did the titre in the mosquito exceed the amount originally ingested or injected.

Transmission of Coxsackie viruses by mosquitoes is theoretically possible since enteroviruses may be present in the blood of infected persons for one or more days in the early stages of certain infections and virus has been isolated from the blood of such persons on many occasions (Yoshioka \& Horstmann, 1959; Gear, 1961-2; Rodrigues et al. 1964; Maguire \& Macnamara, 1966). It is likely that many more isolations would have been reported but for the fact that the viraemic phase is probably over before the onset of symptoms (Yoshioka \& Horstmann, 1959). A blood-sucking arthropod feeding at this critical period could well act as a vector by biting a second uninfected individual even in the absence of active virus multiplication in the mosquito tissue.

The transmission studies were complicated by the fact that mosquitoes generally do not take a second blood meal during the period after infection when virus was shown to be present. A. australis is a rather hardy species which survived handling well and which could be readily induced to take a second blood meal on or after the 10th day after the first meal. In one experiment, 13 of $22 \mathrm{~A}$. australis exposed to new uninfected newborn mice on day 12 took a second full blood meal, but no transmissions were obtained. This would suggest that these mosquitoes may not be very efficient vectors of Coxsackie viruses in nature. On the other hand, C. tonnoiri is a very fragile species which did not survive well in the laboratory and which could only be induced to feed a second time with some difficulty. The transmission of virus by $C$. tonnoiri on days 10 and 13, when there was no detectable virus in the whole ground-up insect, suggests that i.p. plus i.c. inoculation of suckling mice used to detect virus in the mosquito tissue may not be as efficient a method of infecting as inoculation by mosquito bite. Subsequent comparative titrations of Coxsackie A 6 in mice using the combined i.c./i.p. route or the subcutaneous route showed that the subcutaneous route was slightly more sensitive as a method of detecting virus, the mean difference in titre being $10^{0.8} \mathrm{LD} 50$. The possibility that the suspension of mosquito tissue itself was absorbing or inactivating the virus was also tested and it was found that less than $10^{0.5} \mathrm{LD} 50 / \mathrm{ml}$. drop in titre occurred when Coxsackie A 6 was incubated with a mosquito suspension for $1 \mathrm{hr}$. at $37^{\circ} \mathrm{C}$.

With a small number of successful transmissions such as those described above, account must be taken of the possibility that the virus recovered from the newborn mice could have arisen from contamination from some other source. In this case it would be very unlikely that such contamination did occur since virus was only recovered from those mice which were observed to have been bitten by infected mosquitoes, and no other work was being done with Coxsackie A 6 in the laboratory at the time.

The survival of the virus in a transmissible form, either within the mosquito or 
as contamination of the mouth parts, for up to 13 days after feeding indicates that mosquitoes could play some role in the epidemiology of Coxsackie infections in areas of high mosquito population. However, in order to act as an efficient vector, the mosquito would have to bite a second time within a fairly short period.

The original Fiji isolations were all made from $A$.polynesiensis, although nine other species were also captured and tested at the same time. It seems therefore that species may differ in their ability to harbour the virus. This is supported by the present study where A. australis did not transmit, whereas $C$.tonnoiri did, even though considerably fewer second feedings were obtained with the latter.

The effect of temperature on the survival and transmission of Coxsackie A 6 has not been studied here. The two species of mosquito used failed to survive at temperatures much above $20^{\circ} \mathrm{C}$. However, it is quite possible that virus multiplication could occur at the higher temperatures of the area of Fiji where the original isolations were made (mean summer temperature for Suva is $26^{\circ} \mathrm{C}$.), and this possibility deserves further study. Such temperature effects on multiplication have been observed with arboviruses (Davis, 1932; Chamberlain \& Sudia, 1955).

This work was supported by the Medical Research Council of New Zealand. I am grateful to Dr J. S. Pillai for his help with the supply of mosquitoes and to Mrs M. M. Prescott and Mr J. K. Scott for technical assistance.

\section{REFERENCES}

Chamberlain, R. W. \& Sudia, W. D. (1955). The effects of temperature upon the extrinsic incubation of Eastern Equine Encephalitis in mosquitoes. American Journal of Hygiene 62, 295-305.

Dathdorf, G. \& Melnick, J. L. (1965). Coxsackie Viruses, in Viral and Rickettsial Infections of Man, 4th ed., pp. 474-512. Ed. F. L. Horsfall and I. Tamm. Philadelphia: Lippincott.

Davis, N. C. (1932). The effect of various temperatures in modifying the extrinsic incubation period of Yellow Fever virus in Aedes aegypti. American Journal of Hygiene 16, 163-76.

GEAR, J. (196 I-2). Coxsackie viruses in Southern Africa. Yale Journal of Biology and Medicine $34,289-303$.

GELFAND, H. M. (1961). The occurrence in nature of the Coxsackie and ECHO viruses. Progress in Medical Virology 3, 193-244.

Maguire, T. \& Macnamara, F. N. (1966). The isolation of Coxsackie A viruses from human sera and mosquitoes in Fiji. Journal of Hygiene 64, 451-6.

Rodrigues, F. M., W'BB, A., Rowland, U., MYers, R. M. \& GeORge, S. (1964). Isolation of Coxsackie A6 virus from the serum of a case of herpangina in Vellore. Indian Journal of Medical Research 52, 1221-5.

TAYLOR, R. M. (1955). The isolation of Coxsackie and unidentified viruses from human blood and mosquitoes. Proceedings of the 6th International Congress of Microbiology, Rome, 1955. 3, 236-40.

Yoshioka, I. \& Horstmann, D. M. (1959). Viremia in ECHO 9 infection. Federation Proceedings. Federation of American Societies for Experimental Biology 18, 606. 